\title{
Terapi Jiwa Dan Pembentukan Sikap Positif “Wara"' Melalui Puasa Sunnah
}

\author{
Nur Indah Rahmawati \\ MTs Islamiyah, Kemusu Boyolali, Indonesia \\ nurindah@gmail.com
}

\begin{abstract}
Abstrak
Tujuan Penelitian ini adalah untuk mengungkap aktifitas ritual puasa serta sikap atau karakter positif yang dikategorikan sikap wara' dalam dunia pesantren khufadz. Beberapa rumusan masalah yang ingin dijawab diantaranya adalah Bagaimanakah aktifitas puasa sunah dan sikap wara' santri di pondok pesantren Masyithoh? Dalam pelaksanaannya kajian ini lebih bersifat penelitian kuantitatif yang membutuhkan populasi dan sampel. Populasi dan sampel dalam penelitian ini adalah 15 santri yang secara khusus dipilih karena memiliki beban yang lebih khususnya sebagai penghafal Al-Qur'an. Dari hasil kajian ini didapatkan bahwa tingkat aktifitas puasa sunah yang mendapat nilai kategori tinggi sebanyak 15 santri dengan lebar interval antara 24-30 sebesar 100\%, serta tingkat sikap wara' yang mendapat nilai kategori tinggi sebanyak 15 santri dengan lebar interval antara 24-30 sebesar $100 \%$. Dengan demikian bahwa secara singkatnya dunia pesantren sangat kental akan pendidikan karakter sekaligus pembentukan perilaku positif. Dengan aktifitas tersebut mampu memberikan efek terhadap perilaku wara' seorang individu sehingga karakter dan perilaku manusia yang positif terbentuk, hal ini berimplikasi luas pada semakin berkembangnya peradaban Islam yang ada di Nusantara.
\end{abstract}

Kata Kunci: pesantren, puasa, wara', karakter, terapi Islam

\begin{abstract}
The purpose of this study was to reveal the fasting ritual activities as well as positive attitudes or characters categorized as wara 'attitudes in the world of khufadz pesantren. Some formulations of the problem that want to be answered are: How is the activity of sunnah fasting and the
\end{abstract}




\section{Nur Indah Rahmawati}

wara' attitude of the santri in the Masyithoh Islamic boarding school? In its implementation, this study is more of a quantitative research that requires populations and samples. The population and sample in this study were 15 students who were specifically chosen because they had more burden, especially as memorizers of the Qur'an. From the results of this study, it was found that the level of sunnah fasting activity which received a high category score of 15 santri with a width interval between 24-30 by 100\%, as well as the level of wara' attitude which received a high category score of 15 santri with a wide interval between $24-30$ by $100 \%$. Thus, in a nutshell, the world of boarding schools is very identical to character education as well as the formation of positive behavior. With this activity, it is able to have an effect on individuals' wara' behavior so that positive human character and behavior are formed, this has broad implications for the growing development of Islamic civilization in the archipelago.

Key words: boarding school, fasting, wara', character, Islamic therapy

\section{A. Pendahuluan}

Banyak dari kalangan umat Islam yang sangat berhati-hati menjaga sikap wara'. Terutama para penghafal Al-Qur'an, sebab orang yang menghafalkan Al-Qur'an wajib hukumnya mengamalkan isinya. Menghafal Al-Qur'an merupakan suatu perbuatan yang sangat mulia dan sesuatu yang sangat dicita-citakan oleh semua muslim yang sholeh. Meskipun banyak sekali aral dan cobaan yang menghadang selama pendakian, akan terasa mudah bagi orang yang memiliki tekat kuat untuk mencapainya. Hal ini karena Al-Qur'an mampu memberikan syafaat kepada penghafalnya di hari kiamat nanti. Diriwayatkan dari Abu Hurairah r.a bahwa Rasulullah bersabda:

Artinya:" Ketika kiamat nanti, penghafal Al-Qur'an akan didatangkan dan Al-Qur'an berkata, "Wahai Tuhan berikanlah ia pakaian." Maka orang itupun dipakaikan mahkota kehormatan. Al-Qur'an berkata lagi," Wahai Tuhan tambahkan lagi." Maka orang itu diberi pakaian kehormatan. Al-quran 


\section{Terapi Jiwa Dan Pembentukan Sikap Positif “Wara”“ Melalui ...}

berkata lagi," Wahai Tuhan, ridhailah dia." Maka orang itupun diridhai, kemudian dikatakan kepadanya," Bacalah dan tingkatkanlah. Setiap satu ayat akan menambah satu kebaikan".(HR. Tirmidzi, Al-kitab fad\}oilu al lqur'ani 'an rosu<lillah, bab ma ja a fi>man qoroa h\{arfa mina al qur'ani milata minal ajri: 2839).

Khusunya pada pesantren Khufadz Al Qur'an, Para penghafal Al-Qur'an memiliki pengalaman yang berbeda-beda dalam proses penghafalannya. Ada yang mengatakan sangat sulit dan ada pula yang mengatakan biasa saja serta ada pula yang mengatakan sangat mudah. Oleh karena itu banyak dari guru Al-Qur'an atau para kiya'i memberikan ijazah tertentu atau mengajarkan laku tirakat tertentu supaya membantu mempermudah santri menghafal Al-Qur'an. Di antara ijazah tersebut adalah puasa sunah Daud, puasa sunah naun, puasa sunah Senin Kamis dan menjaga sikap wara' dalam kehidupan sehari-hari.

Berangkat dari hal tersebut maka penulis bermaksud mengadakan penelitian tentang bagaimanakah aktifitas puasa sunah dan sikap wara' di Pondok Pesantren "Masyithoh" Dayaan Sidorejo Kidul Tingkir Salatiga. Seperti diketahui kegiatan santri baik itu kajian kitab atau hafalan Al Qur'an senantiasa menjadi kebiasaan para santri Pondok Pesantren "Masyithoh" yang mana notabenya adalah pondok pesantren Al-Qur'an.

Dari rumusan masalah diatas, kajian ini diharapkan untuk dapat mengetahui bagaimana aktifitas puasa sunah serta sikap wara' santri di pondok pesantren "Masyithoh" Dayaan Sidorejo Kidul Tingkir Salatiga. Hipotesis adalah suatu jawaban yang bersifat sementara terhadap permasalahan penelitian sampai terbukti kebenarannya melalui data yang terkumpul (Arikunto, 1991: 62). Berdasarkan kajian-kajian teoritis yang penulis temukan, maka penulis mengajukan hipotesis: bahwa dunia pesantren sangat kental dengan pendidikan karakter dan perkembangan peradaban Islam

Agar tidak terjadi salah penafsiran terhadap judul di atas, maka penulis akan memaparkan penegasan beberapa istilah diantaranya; 1)Aktifitas adalah suatu kegiatan atau kesibukan (Tim Penyusun Kamus Pusat Bahasa, 2007: 36), 2) Puasa sunah bisa disebut juga 
sebagai puasa tathawwu. Tathawwu artinya mendekatkan diri kepada Allah dengan melakukan amal ibadah yang tidak diwajibkan. Menurut kesepakatan para ulama, yang termasuk puasa tathawwu ialah puasa Daud, puasa tiga hari dalam setiap bulan setiap tgl 13, 14, 15, bulan qomariyah, puasa Senin Kamis, puasa enam hari pada bulan Syawal, dan puasa hari Arofah (Al-Zuhayly, 1995: 122).

Puasa sunah tersebut penulis jadikan variabel karena di antara puasa-puasa sunah di atas, santri pondok Pesantren "Masyitoh" melakukannya. Indikator variabel aktifitas puasa sunah adalah: a) Jenis-jenis puasa sunah, b) Frekuensi melaksanakan puasa sunah, c) Halangan melaksanakan puasa sunah, d) Tujuan melakukan puasa sunah

Sikap wara' atau Wara' adalah menghindarkan diri dari sesuatu yang haram dan syubhat (Alaway, 1999: 127). Beberapa indikator variabel sikap wara' adalah: a. Meninggalkan maksiat dan dosa, b. Meninggalkan perkara yang syubhat, c. disiplin, d. Rendah hati

Kajian ini lebih bersifat penelitian kuantitatif yang membutuhkan populasi dan sampel. Menurut Sugiono (2007: 61) populasi adalah wilayah generalisasi yang terdiri atas objek atau subjek yang mempunyai kualitas dan karakteristik tertentu yang ditetapkan oleh peneliti untuk dipelajari dan kemudian ditarik kesimpulannya.

Dalam penelitian ini yang menjadi objek penelitian atau populasinya adalah semua santri putri yang berjumlah 15 santri karena yang menghafal Al-Qur'an hanya santri putri saja di Pondok Pesantren "Masyitoh" Dayaan Sidorejo Kidul kecamatan Tingkir kota Salatiga.

Sampel adalah sebagian atau wakil populasi yang akan diteliti (Arikunto, 1998: 117). Menurut Arikunto (1998: 117) apabila jumlah populasi lebih dari 100, maka sempel dapat diambil 10-15\% atau 2025\%. Dan apabila sempel kurang dari 100 lebih baik diambil semua, sehingga penelitiannya merupakan penelitian populasi. Dalam hal ini sampel secara umum adalah santri mukim sejumlah 15 yang secara khusus melaksanakan hafalan Al Qur'an.

Teknik pengumpulan data dalam kajian ini menggunakan beberapa teknik diantaranya a) Metode Angket yaitu sejumlah 
pertanyaan tertulis yang digunakan untuk mendapatkan data atau informasi dari responden dalam arti laporan tentang pribadinya, atau hal-hal yang ia ketahui (Arikunto, 1998: 140), Metode angket digunakan untuk memperoleh informasi tentang aktifitas puasa sunah dan sikap wara' serta tingkat kelancaran menghafal Al-Qur'an di Pondok Pesantren "Masyitoh" Dayaan Sidorejo Kidul kecamatan Tingkir kota Salatiga; b) Metode Dokumentasi, menurut Rumidi (2004: 131) metode dokumentasi merupakan metode pengumpulan data dengan menggunakan dokumen yang ada. Dengan metode ini dapat diperoleh catatan atau arsip yang berhubungan dengan penelitian. Metode ini penulis gunakan untuk mengetahui situasi dan kondisi sebenarnya di Pondok pesantren "Masyitoh" Dayaan Sidorejo Kidul kecamatan Tingkir kota Salatiga, c) Observasi, Metode observasi adalah pengamatan yang meliputi kegiatan pemusatan perhatian terhadap suatu objek dengan menggunakan seluruh alat indra (Arikunto, 1996: 145).

Teknik analisis kuantitatif yaitu teknik statistik sederhana yang merupakan prosentase analisis berbentuk matematik dalam mengumpulkan, menyusun, menyajikan dan menganalisis. Adapun rumusan yang digunakan untuk mencari prosentase pengaruh aktifitas puasa sunah dan sikap wara' terhadap kelancaran menghafal Al-Qur'an memakai rumus regresi ganda dengan menggunakan analisia SPSS 16.

\section{B. Pembahasan}

\section{Aktifitas Puasa Pembentuk perilaku dan Karakter positif}

Puasa adalah menahan diri dari segala sesuatu yang membatalkan puasa mulai dari terbitnya fajar sampai tenggelamnya matahari. Adapun puasa sunah disebut juga dengan puasa tathawwu yang artinya mendekatkan diri kepada Allah SWT, dengan melakukan amal ibadah yang tidak diwajibkan (Al-Zuhayly, 1995: 123). Istilah tathawwu ini diambil dari ayat berikut: Artinya: Dan barang siapa yang melakukan kebaikan dengan kerelaan hati... (QS Al-Baqarah : 158).

Puasa sunah merupakan amal ibadah sunah yang utama. Meskipun demikian puasa sunah tidak boleh dilakukan oleh orang yang belum mengqadha puasa fardu. Pernyataan ini sesuai dengan 
hadis yang diriwayatkan Ahmad dari Abu Hurairah, bahwa Nabi Muhamad saw bersabda: "Barang siapa yang berpuasa sunah, sedang atasnya ada puasa Ramadhan yang belum diqadha, maka tidaklah diterima dari padanya puasa sunah itu sehingga ia mengerjaka puasa ramadhan (HR. Ahmad, Al-kitaba al-as\}awm, bab s\}awmu ramad\}an: 8267)".

Menurut kesepakatan para ulama, yang termasuk puasa sunah atau puasa tathawwu' ialah sebagai berikut: Pertama, Berpuasa sehari dan berbuka sehari. Puasa ini merupaka jenis puasa tathawwu' yang paling utama, berdasarkan hadis yang terdapat dalam kitab Ash-Shahihain yang berbunyi sebagai berikut: "Puasa yang paling utama ialah puasa Dawud. Dia berpuasa sehari dan berbuka sehari (HR. Bukhori, kitabu al-as\}awmi: bab s\}aumi da<wuda 'la<ihi al-asalam: 1979)".

Kedua, Berpuasa tiga hari dalam setiap bulan, Dalam puasa jenis ini, yang lebih utama ialah berpuasa pada bulan qomariyah saat tiga hari bidh, yakni pada tanggal 13, 14, dan 15. Ketiga hari ini dinamakan bidh karena malam hari pada ketiganya diterangi bulan dan siangnya di terangi matahari. Apabila seseorang melakukan puasa pada hari itu pahalanya akan dilipat gandakan, satu kebaikan dilipat gandakan menjadi sepuluh kebaikan. Dalil puasa ini ialah hadis yang diriwayatkan oleh Abu Dzar, dia mengatakan bahwa Nabi Muhammad saw bersabda kepadanya: "Jika kamu hendak berpuasa tiga hari dalam sebulan, maka berpuasalah pada tanggal 13,14, dan 15 (Imam Ahmad, kita<bu al-as\}aumi, bab yas\} $u<m u$ thalathata ayami: 20465)".

Ketiga, Puasa pada hari Senin dan Kamis dalam setiap Minggu. Puasa jenis ini berdasarkan perkataan Usamah bin Zaid sebagai berikut: "Sesungguhnya Nabi saw berpuasa pada hari senin dan kamis. Lalu ketika beliau ditanya mengenai hal itu, beliau bersabda: Sesungguhnya amalan-amalan manusia diperlihatkan pada hari senin dan kamis (Abu Dawud, al-kitabi al-s\}awmi, bab fis\}awmi lithnayni: 2080)".

Keempat, Puasa enam hari pada bulan Syawal. Melakukan puasa sunah Syawal boleh dilakukan secara tidak beruntun harinya namun apabila dilakukan secara beruntun setelah hari raya lebih utama. Tsauban meriwayatkan hadis sebagai berikut: "Pahala puasa 


\section{Terapi Jiwa Dan Pembentukan Sikap Positif “Wara”“ Melalui ...}

sebulan bulan ramadhan sama dengan puasa sepuluh bulan. Dan puasa enam hari pahalanya sama dengan puasa dua bulan. Dengan demikian, jumlahnya adalah satu tahun (HR. Bukhari, al-kitabu alas\}awmi, bab s\}awmu ramad\}<an :2063)".

Kelima, adalah Puasa hari Arafah, Puasa Arafah yaitu puasa sunah yang dilakukan pada tanggal 9 Dzulhijah bagi orang yang tidak datang melakukan ibadah haji, berdasarkan hadis yang diriwayatkan oleh muslim: Artinya: Berpuasa pada hari Arafah dipandang oleh Allah sebagai amalan yang menjadi kafarat untuk satu tahun sebelumnya dan sesudahnya (HR. Muslim, al-kithab lis\}aymi, bab s\}aymi thalathata aima min kuli shahri wa s\}awmi yawmi 'rofatha: 1976).

Dari beberapa jenis puasa diatas, tentunya sesuatu diperintahkan untuk melaksanakannya bukan berarti karena sebab atau tanpa makna. Akan tetapi pasti dibalik diperintahkannya sesuatu tersebut dikerjakan pasti memiliki manfaat yang luarbiasa bagi pelaksananya. Begitupula hubunganya dengan pelaksanaan Puasa dengan kesehatan baik fisik maupun psikologis seseorang.

Setiap berbicara tentang hubungan puasa dengan kesehatan, maka yang terpikir adalah pengaruh antara menahan lapar dan dahaga di siang hari terhadap kesehatan. Hasil penelitian ini menunjukkan bahwa penyakit psikosomatik mampu dicegah dengan psikoterapi. Jenis- jenis penyakit psikosomatik adalah jantung, stroke, hipertensi, paru-paru, lambung dan kanker. Semisal contohnya penyakit Lambung dapat dicegah dengan cara beribadah kepada Allah dengan melaksankan puasa dan membaca do'a (Fitri Ani Lubis, 2016).

Menurut mantan ketua Ikatan Dokter Indonesia (KDI) Kartono Muhammad (1990), manusia sehat dapat bertahan hidup selama dua minggu meskipun tanpa makanan sama sekali, asal tetap minum air. Sedangkan jika selain tidak makan juga tidak minum sama sekali, ia dapat bertahan selama seminggu. Kalau hanya menahan makan dan minum selama dua belas jam saja tidak ada pengaruh buruk terhadap kesehatan sama sekali. Sebenarnya yang berpengaruh besar bagi kesehatan dalam berpuasa adalah niat dan kemauan untuk menahan nafsu (Musbikin, 2004: 36). 
Sebagaimana kita ketahui, sebagian besar penyakit yang diderita manusia sebenarnya berkaitan dengan perilaku manusia itu sendiri. Contoh penyakit kelamin (akibat "membeli" penyakit dari pelacur), penyakit darah tinggi, jantung, dan penyakit akibat stres termasuk sakit lambung, itu semua sangat erat kaitannya dengan ketidakmampuan menahan diri. Ilmu kedokteran telah membuktikan bahwa mereka yang sedang marah, baik yang dipendam maupun dinyatakan atau sedang "panas hati" oleh sebab apapun akan meningkatkan kadar hormon katekholamin dalam darahnya. Hormon katekholamin ini akan memacu denyut jantung, menegangkan otototot, dan menaikkan tekanan darah. Semua itu jika dibiarkan berlangsung lama akan membahayakan kesehatan dan mempercepat proses ketuaan (Musbikin, 2004: 37).

Ingat akan puasa ketika hendak marah, ketika tidak sabar atau ketika panas hati, akan mematahkan terjadinya peningkatan hormon katekholamin dalam darah. Efek inilah yang sebenarnya lebih besar pengaruhnya terhadap kesehatan dalam pengertian yang positif. Dengan penjelasan di atas dapat di tarik kesimpulan bahwa puasa mengandung pesan agar kita menjaga hidup sehat dan dapat mengendalikan emosi. Degan demikian puasa dapat memberikan manfaat yang besar terhadap kesehatan dan dapat mengatasi stres. Penulis sengaja membahas bab ini karena biasanya para santri yang sedang mencari ilmu mempunyai kecendrungan stres dan tidak sabar dalam melalui fase demi fase pembelajaran.

Hubungan Puasa dengan dunia psikologis sangatlah erat, banyak penelitian yang membuktikan bahwa puasa mampu mengatasi beberapa penyakit Stres dan Mental. Hal ini diperkuat hasil penelitian yang menunjukkan bahwa beberapa gangguan mental baik yang bersifat jasmani maupun rohani bisa disembuhkan dengan puasa Senin Kamis. Selain itu puasa memiliki fungsi sebagai terapi dalam Bimbingan Konseling Islam, baik dari fungsi penyembuhan: mengatasi stress atau tekanan jiwa dan puasa dapat menyembuhkan kecanduan narkoba, fungsi pencegahan: mematahkan kecenderungan jiwa pada maksiat, serta dengan puasa mampu memberikan efek kemampuan pengendalian diri, dan fungsi pembinaan dan pembangunan: puasa mengantar sikap hidup takwa, pengendalian diri, pembinaan kesabaran, dan puasa untuk 


\section{Terapi Jiwa Dan Pembentukan Sikap Positif “Wara”“ Melalui ...}

membentuk kematangan diri (konsistensi dan kejujuran) (Wakhyu Kurniasari, 2015). Dalam hal ini terapi puasa merupakan sebuah aktifitas yang mampu memberikan pengaruh luar biasa dalam pembinaan karakter pribadi yang sempurna.

Dalam setiap diri manusia terdapat naluri berupa dorongandorongan yang bentuknya bermacam-macam. Seperti agresif dalam arti emosional, contohnya mengeluarkan kata-kata kasar, tidak senonoh dan menyakitkan hati. Misalnya akhir-akhir ini semakin banyak terjadi kekerasan, penyelewengan, penumpukan harta yang sebenarnya tidak menjadi haknya. Untuk itu puasa adalah penawarnya, sebab puasa bukan hanya menahan diri dari makan, minum dan bersenggama saja melainkan juga menahan diri dari halhal yang tidak terpuji yang pada ahirnya mengakibatkan stres pada dirinya dan orang lain (Musbikin, 2004:40).

Salah satu ciri jiwa yang sehat adalah kemampuan seseorang untuk menahan diri. Pengendalian diri sangat penting bagi kesehatan jiwa sehingga daya tahan mental dalam menghadapi berbagai stres kehidupan meningkat karenanya. Problem utama kesehatan jiwa adalah timbulnya berbaga stresor psikososial yang mengakibatkan seseorang menderita ketegangan, kecemasan, depresi, ketidakpuasan, ketidakbahagiaan, prasangka buruk, niat jahat, dan sebagainya, dan semua itu dapat di atasi dengan puasa. Selain itu ibadah puasa juga menjunjung tinggi nilai kejujuran terhadap Tuhan,diri sendiri,dan orang lain. Apabila sifat jujur telah tertanam pada diri seseorang, maka dirinya akan merasa tentram, ia tidak akan dihinggapi oleh rasa takut atau rasa berdosa, karena segala sesuatu jelas dan tidak ada yang dipalsu atau disembunyikan (Daradjat, 1989: 32).

Di samping bermanfaat bagi kesehatan jasmani dan mengatasi berbagai penyakit, puasa juga melatih rohani atau jiwa manusia agar menjadi lebih baik. Temuan terahir dunia kedokteran jiwa membuktikan bahwa puasa dapat meningkatkan kecerdasan emosional atau Emotional Quotien(EQ) manusia (Musbikin, 2004: 214).

Daniel Golemon, seorang ahli dan peneliti tentang kecerdasan emosi, pernah mengemukakan sebuah bukti ilmiah tentang puasa 
yang ternyata mampu meningkatkan kecerdasan emosional dan spiritual. Kita simak sebuah cerita dari Daniel sebagai berikut: Anakanak berusia empat tahun di taman kanak-kanak Stanford disuruh masuk ke dalam ruangan. Sepotong marshmallow diletakkan di atas meja di depan mereka. Daniel berkata "kalian boleh makan marshmallow jika mau, tetapi jika kalian memakannya sekembali saya ke sini, kalian berhak mendapatkan satu potong lagi".

Sekitar empat belas tahun kemudian anak-anak itu lulus sekolah lanjutan tingkat atas. Ternyata anak-anak yang dahulu langsung memakan Marshmallow, di banding anak-anak yang mampu menahan diri sehingga mendapatkan dua potong, cenderung tidak tahan terhadap stres, mudah tersinggung dan mudah berkelahi. Meskipun demikian, yang lebih mengejutkan para peneliti adalah munculnya efek yang betul-betul tak terduga: anak-anak yang mampu menahan diri dalam uji Marshmallow di banding dengan yang tidak tahan memperoleh nilai SAT-nya (Scholastic Aptitude Test) yang sudah menjadi standar ujian masuk perguruan tinggi di Amerika dan dunia yang nilai rata-ratanya 210 lebih tinggi (dari nilai tertinggi 1.600) dalam uji masuk perguruan tinggi ( Musbikin, 2004: 215).

\section{Sikap Wara' sebagai pembentukan Perilaku Positif}

Secara harafiah, wara' artinya menahan diri, berhati-hati, atau menjaga diri agar tidak terjatuh pada kecelakaan. Ibn Qoyyim Al Jawzi, dalam Madarij Al-Salikin, mengutip Al-Qur'an surat Almuddatsir ayat 4, sebagai perintah untuk wara' : "Dan pakaian kamu bersihkan". Kata Qotadah dan mujahid makna ayat ini adalah, "Hendaknya kamu membersihkan dirimu dari dosa". Para mufasir sepakat bahwa pakaian adalah kata kiasan untuk diri. Ibnu Abbas sendiri menjelaskan ayat ini bahwa "Jangan kamu busanai dirimu dengan kemaksiatan dan penghianatan" (Rahmat, 1999: 101).

Menurul Imam Al-Ghozali (2004: 361) wara' memiliki empat tingkat, sebagai berikut: Tingkatan pertama, wara' al udul (wara' orang-orang yang memiliki kelayakan moralitas) yaitu menjauhi setiap hal yang harus diharamkan, yang bila dilanggar maka pelanggarnya dinilai melakukan kefasikan dan kemaksiatan.

Tingkatan kedua wara' orang yang was-was contohnya adalah setiap syubhat yang tidak wajib dijauhi tetapi dianjurkan untuk 


\section{Terapi Jiwa Dan Pembentukan Sikap Positif “Wara”“ Melalui ...}

dijauhi. Contohnya orang yang tidak mau berburu binatang karena takut jika buruan itu telah lepas dari pemilik binatang. Sedangkan apa yang dianjurkan untuk dijauhi seperti hadis nabi: "Tinggalkanlah apa yang meragukanmu kepada apa yang tidak meragukanmu (HR. Anasa'i, al-kithab al-ishrabah, bab al-bah\}thu 'la tharki al-shubhati: 5615)".

Tingkatan yang ketiga, wara'al-Muttaqin. Sebagaimana ditegaskan oleh sabda nabi: "Seorang hamba tidak akan mencapai derajat Muttaqin sehingga ia meninggalkan apa yang tidak berdosa karena takut terhadap apa yang berdosa ( HR.Tirmidzi, al-kitab s\}ifatu liqaymati wa liroqo'iq wa<liwaro'i 'n rosu>li al-allahi, bab ma< ja< a fi s\}ifati awani lih\}awd\}i: 2375)".

Diantaranya adalah menghindari perhiasan karena takut akan membawanya kepada dosa yang lain, sekalipun perhiasan itu di bolehkan. Tidak Memakai parfum bagi yang belum menikah, karena parfum dapat menggerakkan syahwat ini termasuk meninggalkan sesuatu yang tidak berdosa karena khawatir terjerumus kepada dosa. Karena kebanyakan hal-hal yang mubah biasanya mengajak kepada yang terlarang (Hawwa, 2004: 362).

Tingkatan keempat, wara' ash-shiddiqin. Pengertian halal menurut mereka adalah setiap hal yang dalam sebab-sebabnya tidak didahului oleh kemaksiatan, tidak dipergunakan untuk kemaksiatankemaksiatan, dan tidak pula dimaksudkan untuk melampiaskan kebutuhan baik sekarang atau kebutuhan yang akan datang. Tetapi dimakan semata-mata karena Allah dan untuk memperkuat ibadah kepadan-Nya dan mempertahankan kehidupan karena-Nya (Muhamad, 2004: 363).

Ini adalah tingkatan muwahhidin (orang-orang yang bertauhid) yang telah terhindar dari tuntutan nafsu mereka, dan memurnikan tujuan hanya kepada Allah. Tidak diragukan bahwa orang yang menghindari hal yang dapat membawanya kepada kemaksiatan pasti menghindari hal yang menyertai kemaksiatan dengan sebab usahanya. Intinya wara' ini menghindari setiap hal yang tidak karena Allah.

Lebih singkatnya, wara' adalah nilai kesucian diri. Orang Islam seharusnya mengukur keutamaan, makna, atau keabsahan gagasan dan tindakan, dari sejauh mana keduanya dapat membuahkan 
penyucian diri. Dalam firman Allah surat Asy-Syams yang artinya" Berbahagialah orang-orang yang mensucikan dirinya, dan celakalah orang yang mencemari dirinya" (QS.91: 9-10). Islam menyeru semua orang untuk berlomba-lomba mensucikan dirinya. Kita semua dipersilahkan mencari kekayaan sebanyak-banyaknya, teman sebanyak-banyaknya, kesibukan sesibuk-sibuknya selama semua itu tidak mencemari diri kita (Rahmat, 1999: 101).

Secara psikologis, setiap kejelekan yang kita lakukan akan membekas dalam hati. Ia akan menjadi noktah hitam yang mengotori hati. Makin banyak kejelekan, makin kotorlah hati. Sehingga apabila kejelekan dilakukan secara terus menerus, hati bukan saja kotor tetapi bahkan telah menjadi kotoran itu sendiri.

Sigmund Freud menemukan hal yang menarik dalam perkembangan manusia. Ia melihat anak-anak kecil bertindak secara impulsif. Mereka melakukan apa saja yang mereka inginkan. Mereka hanya mengejar kesenangan sesaat. Setelah agak besar anak-anak mulai memperhatikan hukuman dan ganjaran dari orang dewasa di sekitarnya. Perlakuannya tunduk pada kontrol dari luar. Ia akan melakukan apa saja yang mendatangkan kesenangan dan menghindari apa saja yang menyebabkan kesusahan. Setelah lebih besar lagi anak-anak mulai mengembangkan kontrol dalam diri. Ia menyerap dan menginternalisasikan nilai, moral dan etika masyarakatnya. Ia berperilaku bukan karena takut siksaan atau mengharapkan ganjaran, tapi ia berperilaku apa yang "seharusnya" ia lakukan (Rahmad, 1999: 104).

Untuk tiga tahap perkembangan ini, Freud menciptakan tiga konsep. Pada tahap pertama anak sepenuhnya diatur oleh Id (sumber hasrat, keinginan dan nafsu). Pada tahap kedua ia melihat realitas disekitarnya, perilakunya diatur oleh ego. Pada tahap ketiga ia diatur oleh hati nuraninya yang disebut dengan superego. Setiap manusia menentang superego-nya setiap ia melakukan pelanggaran nilai-nilai etik atau moral(dalam istilah sufi, setiap ia melakukan kejelekan atau dosa). Ia akan mengalami kegelisahan (kaum psikoanalisis menyebutnya moral anxiety). Konflik dengan superego akan menimbulkan luka psikologis yang dalam. Mungkin luka ini dibenamkan dalam bawah sadar kita, tetapi ia tidak akan hilang. Ia 


\section{Terapi Jiwa Dan Pembentukan Sikap Positif “Wara”“ Melalui ...}

akan menghantui seluruh hidup kita. Perasaan berdosa menimbulkan gangguan fisik dan psikologis.

Para psikolog menyebut kerusakan ini sebagai anxieta disorder. Seorang penderita anxieta disorder mempunyai perasaan sering terganggu detakan jantungnya, tiba-tiba ketakutan, cemas yang menjadikan putus asa, merasa sangat lelah dan kehabisan tenaga, sulit mengambil keputusan, merasa nervous dan tegang terusmenerus, tidak dapat mengatasi kesulitannya sendiri, merasa tertekan, kesulitan konsentrasi, pusing dan sebagainya. Bila seseorang mengalami hal seperti ini berarti dia sedang mempercepat kehancuran dirinya. Salah satu penyebab semua gejala itu adalah perasaan bersalah (Rahmad, 1999: 105).

Perasaan bersalah timbul bila seseorang banyak melakukan kesalahan, kejelekan atau dosa. Karena itu menjauhi perbuatan jelek pada hakekatnya menjaga diri dari kerusakan fisik dan psikologis. inilah fungsi menjaga sikap wara' perlu ditinjau dari sudut pandang psikologis (Rahmat, 1999: 106).

Dalam dunia psikologis dikatakan bahwa perbuatan jelek (dosa) dapat merusak tubuh dan jiwa. Dosa yang dilakukan seseorang juga merusak perbuatan baiknya. Imam Bukhari menyatakan "Aku sudah mendatangi berbagai negeri dan kota. Semua ulama' sepakat bahwa iman itu bisa bertambah dan berkurang. Bertambah karena taat dan berkurang karena maksiat". Jadi dengan wara' atau menjauhi kejelekan, berarti seseorang telah menghilangkan faktor yang mengurangi iman. Menjauhi maksiat pada hakekatnya adalah memelihara imannya (Rahmad, 1999: 109).

Selain uraian diatas, menurut beberapa ahli telah merumuskan bahwa seseorang yang memiliki sikap Wara' mampu dengan mudah Mempelajari Ilmu dan meraih impian. Abdullah bin Mas'ud berkata "Sesungguhnya saya mengira seseorang yang melupakan ilmu yang telah diajarkan kepadanya adalah karena dosa yang telah dilakukannya" (Salim, 2009: 165).

Imam Abu Hanifah bila menemui masalah masalah yang menyulitkannya, ia berkata kepada sahabatnya, "Ini tidak lain karena dosa yang telah saya lakukan". Kemudian ia beristigfar dan sholat maka tersingkaplah masalah itu. Lalu ia berkata "Aku berharap semoga aku diampuni”. Hal itu sampai kepada Fudhail bin Iyadh, lalu 
ia pun menangis dan berkata," Itu karena dosanya yang sedikit, sedangkan selain darinya tidak ada yang menyadarinya"(Salim, 2009: 166).

Ibnu al-Qayyim berkata dalam kitabnya al-Fawa'id, "Dosa-dosa itu seperti luka-luka yang terkadang membawa pada kematian. Tidaklah seseorang dicambuk lantaran dosa yang lebih besar dari kekerasan hati dan jauh dari Allah swt. Hati yang paling menjauh dari Allah adalah hati yang keras, apabila hati menjadi keras, maka mata menjadi kering. Keras hati itu datang karena empat hal diantaranya: banyak makan, banyak tidur, banyak bicara, dan banyak bergaul". Di antara dampak-dampak maksiat, sebagaimana dikatakan oleh Ibnu al-Qayyim dalam jawabannya adalah terhalangnya ilmu pengetahuan. Karena ilmu adalah cahaya yang Allah hujamkan ke dalam hati, sedangkan maksiat memadamkan cahaya itu (Salim, 1999: 167).

Dari penjelasan di atas dapat disimpulkan bahwa orang yang melakukan maksiat atau bisa disebut orang yang tidak bisa menjaga sikap wara' akan sulit menghafal dan mempelajari suatu ilmu yang sudah diajarkan kepadanya. Oleh sebab itu apabila seseorang dapat menjaga sikap wara' dan menjauhi maksiat, insyaallah Allah akan menganugrahi ilmu kepadanya dan akan sangat mudah bagi orang tersebut untuk memghafal dan mempelajari ilmu.

\section{Analisis aktifitas Puasa dan sikap Wara' Santri}

\section{a. Analisis aktifitas Puasa}

Untuk mengetahui aktifitas puasa sunah, penulis menggunakan instrumen berupa angket yang terdiri dari sepuluh item pertanyaan dan menyediakan tiga kriteria jawaban dengan kategori sebagai berikut: Kriteria jawaban A memiliki nilai 3, Kriteria jawaban B memiliki nilai 2, Kriteria jawaban C memiliki nilai 1.

Langkah selanjutnya adalah mencari interval dengan menggunakan norma ideal. Untuk aktivitas puasa sunah dengan jumlah pertanyaan 10 item, Rumus pencarian interval adalah sebagai berikut:

$$
i=\frac{\left(N t-N_{r}\right)+1}{3} \quad i=\frac{(30-10)+1}{3}
$$


Terapi Jiwa Dan Pembentukan Sikap Positif “Wara”“ Melalui ...

Keterangan:

$$
\begin{aligned}
& i=\frac{21}{3} \\
& i=7
\end{aligned}
$$

i : Interval

$\mathrm{Nt}$ : Nilai tertinggi

$\mathrm{Nr}$ : Nilai terendah

Kemudian dimasukkan tabel untuk mengetahui berapa santri yang melakukan aktivitas puasa sunah.

Tabel 1

Interval Aktivitas Puasa Sunah

\begin{tabular}{ccc}
\hline Lebar Interval & Jumlah Santri & Nilai Nominal \\
\hline $24-30$ & 15 & $\mathrm{~A}$ \\
\hline $17-23$ & 0 & $\mathrm{~B}$ \\
\hline $10-16$ & 0 & $\mathrm{C}$ \\
\hline
\end{tabular}

Dari tabel di atas diketahui bahwa :

1) Jumlah santri yang menjawab kategori A dalam angket aktivitas puasa sunah dengan lebar interval 24-30 sebanyak 15 santri.

2) Jumlah santri yang menjawab kategori $B$ dalam angket aktivitas puasa sunah dengan lebar interval 17-23 sebanyak 0 santri.

3) Jumlah santri yang menjawab kategori $C$ dalam angket aktivitas puasa sunah dengan lebar interval $10-16$ sebanyak 0 santri.

Setelah diketahui jumlah santri yang melakukan aktivitas puasa sunah dengan kategori A, B dan C kemudian dicari prosentasinya masing-masing dengan rumus sebagai berikut:

$$
\begin{aligned}
& P=\frac{F}{N} x 100 \% \\
& \text { a. } P=\frac{15}{15} \times 100 \% \\
& \text { Keterangan: } \\
& P=100 \% \\
& \mathrm{P}=\text { Persentase } \\
& \mathrm{F}=\text { Frekuensi } \\
& \mathrm{N}=\text { Jumlah responden } \\
& \text { b. } P=\frac{0}{15} \times 100 \% \\
& P=0 \%
\end{aligned}
$$




$$
\text { c. } \begin{aligned}
P & =\frac{0}{15} \times 100 \% \\
P & =0 \%
\end{aligned}
$$

Keterangan:

1) Prosentase santri yang menjawab dengan kategori tinggi dalam angket aktivitas puasa sunah atau mendapat nominal A sebanyak $100 \%$

2) Prosentase santri yang menjawab kategori sedang dalam angket aktivitas puasa sunah atau mendapat nominal B sebanyak $0 \%$

3) Prosentase santri yang menjawab kategori rendah dalam angket aktivitas puasa sunah atau mendapat nominal $\mathrm{C}$ sebanyak $0 \%$

Tabel 2

Tabel Distribusi Frekuensi Variabel X1

\begin{tabular}{ccccc}
\hline No & $\begin{array}{c}\text { Nilai Aktivitas } \\
\text { Puasa Sunah }\end{array}$ & Interval & Frekuensi & Prosentase \\
\hline 1 & Tinggi & $24-30$ & 15 & $100 \%$ \\
\hline 2 & Sedang & $17-23$ & 0 & $0 \%$ \\
\hline 3 & Rendah & $10-16$ & 0 & $0 \%$ \\
\hline \multicolumn{2}{r}{} & & 15 & $100 \%$ \\
\hline
\end{tabular}

\section{b. Analisis data tentang Sikap wara'}

Untuk mengetahui sikap wara' santri, penulis menggunakan instrumen beberapa angket yang terdiri dari sepuluh item pertanyaan dan menyediakan tiga kriteria jawaban dengan kategori sebagai berikut:

1) Kriteria jawaban A memiliki nilai 3

2) Kriteria jawaban B memiliki nilai 2

3) Kriteria jawaban $\mathrm{C}$ memiliki nilai 1

Setelah nilai angket tentang sikap wara' didapatkan. Langkah selanjutnya kemudian mencari interval untuk sikap wara' dengan menggunakan norma ideal, dengan jumlah pertanyaan 10 item, maka berdasarkan rumus interval di capai hasil sebagai berikut: 
Terapi Jiwa Dan Pembentukan Sikap Positif “Wara”“ Melalui ...

$$
i=\frac{\left(N_{t}-N_{r}\right)+1}{3}
$$

Keterangan:

$$
i=\frac{(30-10)+1}{3}
$$

$$
\begin{array}{ll}
\mathrm{i}=\text { Interval } & i=\frac{21}{3} \\
\mathrm{Nt}=\text { Nilai tertinggi } & i=7
\end{array}
$$

Kemudian dimasukkan ke dalam tabel untuk mengetahui tingkatan sikap wara' santri Masyitoh.

\section{Tabel 2}

Interval Tingkatan Sikap Wara'

\begin{tabular}{cccc}
\hline No & Lebar Interval & Jumlah & Nilai Nominal \\
\hline 1 & $24-30$ & 15 & $\mathrm{~A}$ \\
\hline 2 & $17-23$ & 0 & $\mathrm{~B}$ \\
\hline 3 & $10-16$ & 0 & $\mathrm{C}$ \\
\hline
\end{tabular}

Dari tabel di atas diketahui bahwa :

1) Jumlah santri yang menjawab kategori A dalam angket sikap wara' dengan lebar interval 24-30 sebanyak 15 santri

2) Jumlah santri yang menjawab kategori B dalam angket sikap wara' dengan lebar interval 17-23 sebanyak 0 santri

3) Jumlah santri yang menjawab kategori $C$ dalam angket sikap wara' dengan lebar interval 10-16 sebanyak 0 santri

Setelah diketahui jumlah santri yang menjaga sikap wara' dengan kategori nilai $\mathrm{A}, \mathrm{B}$ dan $\mathrm{C}$ kemudian dicari prosentasi masingmasing dengan rumus sebagai berikut:

$$
P=\frac{F}{N} x 100 \%
$$

Keterangan:

$\mathrm{P}=$ Presentase

$\mathrm{F}=$ Frekuensi

$\mathrm{N}=$ Jumlah responden a. $P=\frac{15}{15} \times 100 \%$

$$
P=100 \%
$$

b. $P=\frac{0}{15} \times 100 \%$

$$
P=0 \%
$$

c. $P=\frac{0}{15} \times 100 \%$

$$
P=0 \%
$$


Keterangan:

1) Prosentase santri yang menjawab dengan kategori tinggi dalam angket sikap wara' atau mendapat nominal A sebanyak $100 \%$

2) Prosentase santri yang menjawab kategori sedang dalam angket sikap wara' atau mendapat nominal B sebanyak $0 \%$

3) Prosentase santri yang menjawab kategori rendah dalam angket sikap wara' atau mendapat nominal C sebanyak $0 \%$

\section{Simpulan}

Setelah penulis mengumpulkan data dalam rangka membuktikan hipotesis yang diajukan dan mengolahnya dengan teknik statistik dengan menggunakan rumus regresi ganda, selanjutnya penulis dapat menarik kesimpulan dari kajian penelitian ini sebagai berikut.

Tingkat aktifitas puasa sunah santri dapat disimpulkan sebagai berikut: a) Tingkat aktifitas puasa sunah yang mendapat nilai kategori tinggi sebanyak 15 santri dengan lebar interval antara 24-30 sebesar $100 \%$, b) Tingkat aktifitas puasa sunah yang mendapat nilai kategori sedang sebanyak 0 santri dengan lebar interval antara 1723 sebesar $0 \%, c)$ Tingkat aktifitas puasa sunah yang mendapat nilai kategori rendah sebanyak 0 santri dengan lebar interval antara 1016 sebesar $0 \%$.

Sikap wara' santri dapat disimpulkan sebagai berikut: a) Tingkat sikap wara' yang mendapat nilai kategori tinggi sebanyak 15 santri dengan lebar interval antara 24-30 sebesar $100 \%$, b) Tingkat sikap wara' yang mendapat nilai kategori sedang sebanyak 0 santri dengan lebar interval antara 17-23 sebesar 0\%, c) Tingkat sikap wara' yang mendapat nilai kategori rendah sebanyak 0 santri dengan lebar interval antara 10-16 sebesar $0 \%$.

Dengan demikian bisa dilihat bahwa pesantren memiliki sumbangan besar dalam pembentukan karakter yang juga sekaligus pembentukan peradaban Islam. Dengan aktifitas puasa sekaligus akan mampu memberikan efek terhadap perilaku wara' seperti rendah hati, berbuat baik, menjauhi maksiat dan sebagainya. Dengan 
Terapi Jiwa Dan Pembentukan Sikap Positif “Wara”“ Melalui ...

adanya beberapa aktifitas tersebut secara langsung memberikan pengaruh luarbiasa bagi perubahan perilaku manusia yang positif sehingga dalam hal ini karakter positif senantiasa terjaga dan terlestarikan dengan baik. 


\section{Daftar Pustaka}

Al Ghozali, Imam. tt, Terjemah Ihya Ulumudin. Semarang: CV Assyifa. Alaway, Abdullah. 1999. Sentuhan-Sentuhan Sufistik. Mesir: Pustaka Setia.

Al-Qaradhawi, Yusuf. 2007. Menumbuhkan Cinta Kepada Al-Qur'an. Pres, Yogyakarta: Mardhiyah.

Al-Zuhayly, Wahbah. 1995. Puasa dan Itikaf. Damaskus: Dar al-fikri. Arikunto, Suharsimi.1998. Prosedur Penelitian Suatu Pendidikan Praktis Revisi. Jakarta: Rineka cipta. . 1996. Prosedur Pendidikan Suatu Pendekatan Praktis. Jakarta: Rineka cipta.

Badwilan, Ahmad Salim. tt, Panduan Cepat Menghafal Al-Qur'an. Jogjakarta: Diva pres.

Fitri Ani Lubis, (2016) METODE PSIKOTERAPI PENCEGAHAN PENYAKIT PSIKOSOMATIK MENURUT MUHAMMAD UTSMAN NAJATI. Skripsi thesis, Universitas Islam Negeri Sultan Syarif Kasim Riau.

Ghozali, Imam.2001. Aplikasi Analisis Multivariate Dengan Program SPSS. Semarang: Undip.

Habibillah, Muhammad. 2011. Kiat Mudah Menghafal Al-Qur'an. Solo: Gazzamedia.

Mas'ud, Abdurrahman. 2005. Reproduksi Ulama Di Era Globalisasi. Yogyakarta: Pustaka pelajar.

Muskibin, Imam. tt, Rahasia Puasa Bagi Kesehatan Fisik dan Psikis. Yogyakarta: Mitra pustaka.

Mustaqim, Abdul. 2007. Strategi Menghafal Al-Qur'an 10 Bulan Khatam, Yogyakarta: Idea Pres.

Rakhmat, Jalaluddin.1999. Membuka Tirai Kegaiban. Bandung: Mizan. Sa'id Hawwa, Said bin Muhammad. 2004. Mensucikan Jiwa. Jakarta: Darus salaam.

Sensa, Muhamad Drajat.2004. Qur'anic Quontient Kecerdasankecerdasan Bentukan Al-Qur'an. Jakarta: Hikmah.

Sugiono. 2010. Statistika Untuk Penelitian. bandung: Alfabeta.

Tim Penyusun Kamus Pusat Bahasa: 2007. Kamus Besar Bahasa Indonesia. 
Terapi Jiwa Dan Pembentukan Sikap Positif “Wara”“ Melalui ...

Wakhyu Kurniasari, (2015) Nilai-Nilai Therapeutic Puasa Senin Kamis Dalam Mengatasi Gangguan Mental Dalam Bimbingan Konseling Islam. Skripsi thesis, UIN Sunan Kalijaga Yogyakarta 